\title{
A háztartások befektetési döntéseinek vizsgálata nemzetközi adatokon*
}

\author{
Balogh Eszter - Kékesi Zsuzsa - Sisak Balázs
}

A tanulmány azokat a gazdasági, demográfiai és kockázatvállalással kapcsolatos tényezőket kívánja meghatározni, amelyek befolyásolják a háztartások kockázatos pénzügyi eszközök iránti keresletét. Az elemzéshez a háztartások vagyonára vonatkozó kérdöives felmérés eredményeit tartalmazó adatbázist (Household Finance and Consumption Survey - HFCS) használtuk fel. A kockázatos eszközök tartása szempontjából az eszközök kínálata is meghatározó, ezért klaszteranalizissel a tökepiaci jellemzök alapján több országcsoportot azonosítottunk. A tanulmányban elsősorban azokra az országokra fókuszálunk, amelyek a tőkepiaci jellemzök alapján Magyarországhoz hasonlóan kevésbé aktívnak tekinthetök, de az összevetés végett bemutatjuk az aktivabb tökepiaccal rendelkező országok jellemzőit is. Az empirikus irodalom alapján ökonometriai eszközökkel vizsgáljuk a kockázatos eszközök keresletét, elkülönítve a szignifikáns tényezők hatását. Ennek megfelelően logit modellt írtunk fel a keresleti tényezökre vonatkozóan külön-külön az általunk vizsgált, kevésbé fejlett és fejlett tökepiaccal rendelkező országcsoportokra. Az eredményeink - miszerint a jövedelem, a vagyon, a képzettség és a kockázatvállalás pozitivan befolyásolja a kockázatos eszköztartást, míg a likviditáskorlát és a háttérkockázatok negativan - megfelelnek az elözetes várakozásainknak, és robusztusnak tekinthetök.

Journal of Economic Literature (JEL) kódok: D14, D31, E21

Kulcsszavak: jövedelem, megtakarítás, pénzügyi eszközök, háztartás

\section{Bevezetés}

A széleskörü empirikus megfigyelések alapján a háztartások csak igen alacsony, az elméletileg optimálisnál jóval kisebb arányban tartanak kockázatos pénzügyi eszközöket, például részvényeket ${ }^{1}$. A portfólióválasztás elmélete magasabb részvénytartást indokolna, mint ami az adatokból adódik. Az elméleti szintnél alacsonyabb

\footnotetext{
* A jelen kiadványban megjelenő írások a szerzők nézeteit tartalmazzák, ami nem feltétlenül egyezik a Magyar Nemzeti Bank hivatalos álláspontjával.

Balogh Eszter a Magyar Nemzeti Bank junior elemzője.E-mail: baloghes@mnb.hu

Kékesi Zsuzsa a Magyar Nemzeti Bank vezető közgazdasági elemzője. E-mail: kekesizs@mnb.hu

Sisak Balázs a Magyar Nemzeti Bank vezető közgazdasági elemzője. E-mail: sisakb@mnb.hu

A magyar nyelvű kézirat első változata 2018. szeptember 25-én érkezett szerkesztőségünkbe.

DOI: http://doi.org/10.25201/HSZ.18.1.6190

${ }^{1}$ A tanulmányban a kockázatos eszközökön a pénzügyi eszközöket értjük, ahol a reáleszközökről is szó van, azt külön jelezzük.
} 
részvénytartás az országok széles körére, a fejlett országokra is jellemző: a háztartások a kockázati prémiumból adódó magasabb hozamok ellenére alulsúlyozzák a portfóliójukban a részvényeket (Zhan 2015). Ennek egy szemléletes példája, hogy az Amerikai Egyesült Államokban azon háztartások közül, amelyeknek likvid eszközei elérik a 100000 dollárt, csak mintegy fele tart részvényt - a magyar háztartások részvénykitettsége viszont még nemzetközi összehasonlításban is alacsony. Magyarországon a közvetlen mellett a közvetett, vagyis a pénzügyi intézményeken (biztosítók, nyugdíjpénztárak, befektetési alapok) keresztül tartott részvényvagyon is alacsonynak mondható nemzetközi összehasonlításban, ugyanakkor itt az elmaradás kisebb mértékú.

A háztartások kérdőíves felmérésén (Household Finance and Consumption Survey - HFCS) elkészítésével alapuló mikroadatbázis lehetővé teszi a makroadatok által jelzett, alacsony kockázatoseszköz-kitettség okainak vizsgálatát. ${ }^{2}$ Az eddig három hullámban elvégzett, az eurozóna országait magában foglaló háztartási szintű adatfelvételt Magyarország önkéntes alapon ${ }^{3}$ végezte el a második hullámtól (2014-től) kezdve, a legutóbbi felmérés 2017-ben volt. Hazánkban a felmérésbe több mint hatezer háztartást vontak be mindkét adatfelvétel során, a második hullám teljes mintaelemszáma meghaladja a 84 ezret (országok szerinti mintaelemszámról és a referenciaévről a Függelék 5. táblázatában található információ). A háztartások pénzügyi eszközeire és tartozásaira vonatkozó kérdések mellett a kérdőív kitér a demográfiai jellemzőkre és a fogyasztási szokásokra is - összességében a legszélesebb körű adatgyűjtés az Európai Unióban. ${ }^{4}$ A kockázatos eszközök tartását befolyásoló tényezők azonosításához használt adatok forrása a felmérés második hullámának adatbázisa (továbbiakban HFCS).

Tanulmányunkban arra a kérdésre keressük a választ, hogy mitöl függ, hogy egy háztartás tart-e kockázatos pénzügyi eszközöket, amelyek közé a tözsdei részvényeket és a befektetési alapokat soroljuk. Az elemzés elsődleges célja azoknak a háztartási - demográfiai, jövedelmi és vagyoni - jellemzőknek az azonosítása, amelyek szerepet játszhatnak a háztartások kockázatos pénzügyi eszközök iránti keresletében. Ugyanakkor úgy véljük, hogy adott országban a háztartások keresletét érdemben befolyásolják a kockázatos pénzügyi eszközök kínálatának jellemzői - például a szükséges információhoz való hozzájutás költsége vagy a vállalatok jellemző finanszírozási formája. A logisztikus regresszióba több országot is bevontunk a megfelelő mintaelemszám és így a robusztus eredmények elérése érdekében, amely összevo-

\footnotetext{
${ }^{2}$ A HFCS adatbázishoz hozzáférést az Európai Központi Bank (EKB) vonatkozó oldalán (https://www.ecb.europa. eu/pub/economic-research/research-networks/html/researcher_hfcn.en.html) leírtaknak megfelelően, a kutatási cél ismertetésével lehet igényelni.

${ }^{3}$ Magyarország mellett Lengyelország is önkéntes alapon végzi el a felmérést.

${ }^{4}$ Ugyanakkor érdemes felhívni rá a figyelmet, hogy a mikrostatisztikák esetében gyakran felmerülő probléma a legmagasabb és a legalacsonyabb jövedelmi rétegek elérése - a legvagyonosabbak számbavételénél a jövedelemeltitkolás merül fel reális problémaként. Ennek megoldására a legtöbb, HFCS felmérésben részt vevő ország úgy tervezi meg a kérdőívet, hogy igyekszik a vagyonos háztartásokat túlsúlyozni, de ennek hatékonysága módszerenként eltérő (EKB 2018).
} 
nást a kínálati jellemzők alapján végeztünk el. A kínálati oldal jellemzőinek kontrollálásakor a tőkepiaci mélységet vettük figyelembe, amelynek számszerűsítéséhez a Worldbank Global Financial Development adatbázisában elérhető tőzsdepiaci jellemzőket alkalmaztuk. Ez alapján végül két országcsoportot emeltünk ki: aktív, illetve kevésbé aktív tőkepiaccal rendelkező országok csoportját. ${ }^{5}$ Összességében Magyarországot olyan országokkal vontuk össze, ahol ezek a kínálati jellemzők hasonlóak, így a hazánkat is tartalmazó országcsoportra felírt regresszió eredményeit a magyar háztartásokra is érvényesnek tekintjük.

Tanulmányunk második fejezetében az elméleti háttér felrajzolása után bemutatjuk a kockázatos eszköztartást meghatározó tényezőkkel foglalkozó tanulmányokat, valamint az elemzésünk kereteit. A harmadik fejezetben ismertetjük a klaszteranalízis alapú országcsoportképzés folyamatát, amellyel a kínálati tényezőket kívánjuk megragadni. Végül, a negyedik fejezetben ismertetjük a modellt és a becslési eredményeket.

\section{Elméleti háttér és elemzési keret}

A háztartások kockázatos eszköztartásának elméleti kereteit egyrészt a háztartások megtakarítási döntéseit vizsgáló kutatások, másrészt a befektetési döntések során diverzifikálást javasló portfólióelmélet alapozta meg. Míg a háztartások megtakarításának szintje korábban is foglalkoztatta a kutatókat, a portfólióválasztás csak később került a figyelem középpontjába. A modern portfólióelmélet alapjait Harry M. Markowitz (1952) amerikai közgazdász fektette le 1952-ben, a The Journal of Finance pénzügyi lapban megjelent Portfolio Selection című tanulmányával. Az elmélet egyik legfontosabb megállapítása, hogy a befektetők a hozammaximalizálás mellett az észlelt kockázat csökkentése érdekében a befektetési döntéshozatal során diverzifikálnak, azaz egyidejúleg több különböző értékpapírba fektetik likvid eszközeit. A portfólióelmélet eredményeit kezdetben nem övezte nagy érdeklődés, mivel nem ismerték fel a jelentőségét. Sharpe (1964) és Lintner (1965) tanulmányában Markowitz eredményeit a tőkepiaci árfolyam modell (CAPM) megalkotásához használta fel, ami az értékpapírok kockázatának és várható hozamának egyensúlyi kapcsolatát írja le. A CAPM-modell igazolta, hogy a portfólióelmélet eredményei a gyakorlatban is alkalmazhatók.

Az empirikus megfigyelések szerint azonban a befektetők - vélhetően az információs korlátok megléte és a korlátozott racionalitás miatt - nem az elméletnek megfelelö módon diverzifikálják a portfóliójukat. A kutatók a gyakorlati tapasztalatokat igyekeztek az elméletben is figyelembe venni. Kahneman és Tversky (1979) elmélete szerint

\footnotetext{
${ }^{5}$ Az aktív tőkepiaccal rendelkező országok közé Hollandiát, Franciaországot, Németországot és Finnországot soroltuk, míg a kevésbé aktív tőkepiaccal jellemezhető országok csoportjába Litvánia, Görögország, Magyarország, Lengyelország, Észtország, Portugália, Ausztria, Szlovénia és Ciprus tartozik. A két országcsoportban megközelítőleg 21 - 23 ezer háztartás található (EKB 2016b).
} 
a nem megfelelő diverzifikációk egyik lehetséges magyarázata, hogy a befektetők a kockázatokat aszimmetrikusan észlelik. A kilátáselmélet (prospect theory) alapján az egyének hajlamosak a veszteségeket nagyobb mértékben figyelembe venni, mint a nyereséget. Az elméletek szintjén ezt úgy próbálták például kezelni, hogy különböző rugalmasságokat alkalmaztak az alulteljesítő piacokon (Bawa - Lindenberg 1977) vagy a várt volatilitás helyett az alulteljesítő piac volatilitását használták (Harlow 1991). Az empirikus megfigyelések arra is felhívták a figyelmet, hogy a befektetők sokkal nagyobb súllyal veszik figyelembe a közelmúlt eseményeit. Benatzi és Thaler (1995) rövidlátó veszteségkerülés (myopic loss aversion: MLA) elmélete a veszteségelkerülést ötvözi egy másik viselkedési közgazdasági koncepcióval, Kahneman és Tversky (1984) mentális könyvelésével (mental accounting). King és Leape (1998) szerint a háztartások portfólióválasztási döntései nem magyarázhatók a hagyományos portfólióválasztási modellel, mert a háztartások nem diverzifikálnak. Ennek oka egyrészt, hogy a háztartások fogyasztási és befektetési döntései keveredhetnek, másrészt a jobban diverzifikált portfólió kezelése költségesebb.

Az életkor nemcsak a háztartások megtakarításának szintjét, hanem összetételét is befolyásolhatja. Az életciklus-hipotézis szerint az idősebb háztartásoknak növelnie kellene a megtakarításaikat és kevésbé kellene kockázatos eszközöket tartania (Cocco et al. 2005). Ezt Bodie és társai (1992) is megerősítik, és azzal magyarázzák, hogy az idősebb háztartásokkal szemben a fiatalabb befektetők nagyobb munkaerőpiaci rugalmassággal rendelkeznek, így jobban tudják az ebből származó sokkokat diverzifikálni. King és Leape (1987) ugyanakkor azt állapította meg, hogy az életkor pozitívan befolyásolja a kockázatos eszközök tartásának valószínúségét, még akkor is, ha a vagyonhatást kiszúrik. Ezt az alaposabb pénzügyi ismeretekkel magyarázzák, ami az idő múlásával feltehetően növekszik. Szintén az idősebb háztartások magasabb részvénytartását igazolja Paxson (1990), aki szerint a fiatal háztartások gyakran szembesülnek likviditási korláttal, ami miatt elsősorban a viszonylag biztonságosnak tartott, likvid eszközöket preferálják. Néhány tanulmány szerint a kockázatos eszközök tartása az életpálya elején növekszik, majd egy idő után csökken.

A portfólióválasztás elmélete a kérdőíves felmérések elterjedésével egyre inkább az empíria felé fordult. A portfólióválasztás elmélete ugyan fogalmaz meg normativ állításokat a háztartások portfólióallokációs döntéseiről, de a lakosság döntéseit leíró empirikus kutatások még viszonylag új területnek számítanak. A pénzügyi szektor liberalizációja és modernizációja a háztartások eszközallokációjára is hatással volt: az újabb és újabb eszközök megjelenése jelentősen átformálta a pénzügyi piacokat. A kutatók figyelmének középpontjába a mikroadatbázisok kerültek, és olyan kérdésekre kezdték el keresni a válaszokat, hogy a háztartások eszközallokációját milyen tényezők befolyásolják. A legtöbb tanulmány a tőzsdei részvények arányát próbálta megmagyarázni, mivel az empirikus megfigyelések alapján a magas kockázatkerülés miatt a háztartások csak igen alacsony arányban tartanak részvényeket, ami nem 
magyarázható a standard portfólióválasztási elmélettel. Az ezzel a témával foglalkozó irodalmat kockázati prémium rejtélynek is nevezik (Gollier 2001).

Az empirikus irodalom leggyakrabban a háztartások tözsdei részvényekben tartott vagyonát vizsgálja, amelyről elmondható, hogy jelentősen elmarad az elmélet alapján várt szinttől. A nemzetközi empirikus adatok azt mutatják, hogy bár a háztartások számottevő része megtehetné, mégsem fektet részvényekbe. Az általunk vizsgált európai országokban a háztartások, amelyek legalább 50 ezer eurós bankbetéttel rendelkeznek, átlagosan csak 27 százalékban birtokolnak részvényeket. Az ebbe a csoportba tartozó finn háztartások azok, ahol a legmagasabb, több mint 50 százalékos a részvénnyel rendelkezők aránya, míg Görögországban ugyanez az érték csupán 4 százalék. Ez alapján elmondható, hogy a háztartások jelentős része távol tartja magát a részvénypiactól. A nemzetközi összehasonlítást tekintve a nyugat-európai országokban jellemzően magasabb, míg a kelet-európai országokban - köztük Magyarországon is - alacsony a részvénnyel rendelkező háztartások aránya. A 2014re rendelkezésre álló nemzetközi adatok szerint szintén az alacsonyabb aránnyal rendelkező országok közé sorolható a két balti-állam, Észtország és Lettország, továbbá a szuverén adósságválság által is súlyosan érintett Görögország. Hazánkban a HFCS-adatbázis 2014-es felmérése alapján a háztartások 1,3 százaléka tartott tőzsdei részvényt a portfóliójában.

\subsection{A kínálati oldal szerepe}

A háztartások közvetlen tőzsdei részvénytartása és a nem pénzügyi vállalatok részvényben történő finanszírozása között erös kapcsolat mutatható ki (1. ábra). A vállalatok számára szükséges forrásokat részben a banki hitelek finanszírozásán keresztül, részben közvetlenebb módon, vállalati részvények vásárlásával is biztosíthatják a háztartások. A fejlettebb európai gazdaságokban az utóbbi értéke általában meghaladja vagy megközelíti a GDP 10 százalékát. Ezzel összehasonlítva Magyarországon a háztartások által tartott részvények értéke mindössze a GDP 2 százalékát teszi ki (érdemes megjegyezni, hogy a lakossági részvényvagyonnak nem csak a GDP-hez, hanem a pénzügyi eszközökhöz viszonyított aránya is hasonló rangsort eredményezne). Fontos ugyanakkor azt is figyelembe venni, hogy a fejlettebb országokban a nem pénzügyi vállalati szektor akár a GDP 100 százalékát is meghaladó részvényforrásokkal is rendelkezhet, míg Magyarországon ennek mértéke csupán a GDP 20 százalékát teszi ki. Így bár a szakirodalom elsősorban a részvények iránt mutatkozó kereslet hatását helyezi előtérbe, a lakosság kereslet oldali tényezői mellett vélhetően a vállalati szektor - kínálat oldali - forrásszerkezetének is változáson kell átmennie ahhoz, hogy a lakossági finanszírozás értéke emelkedhessen - akár közvetett, akár közvetlen finanszírozáson keresztül. 


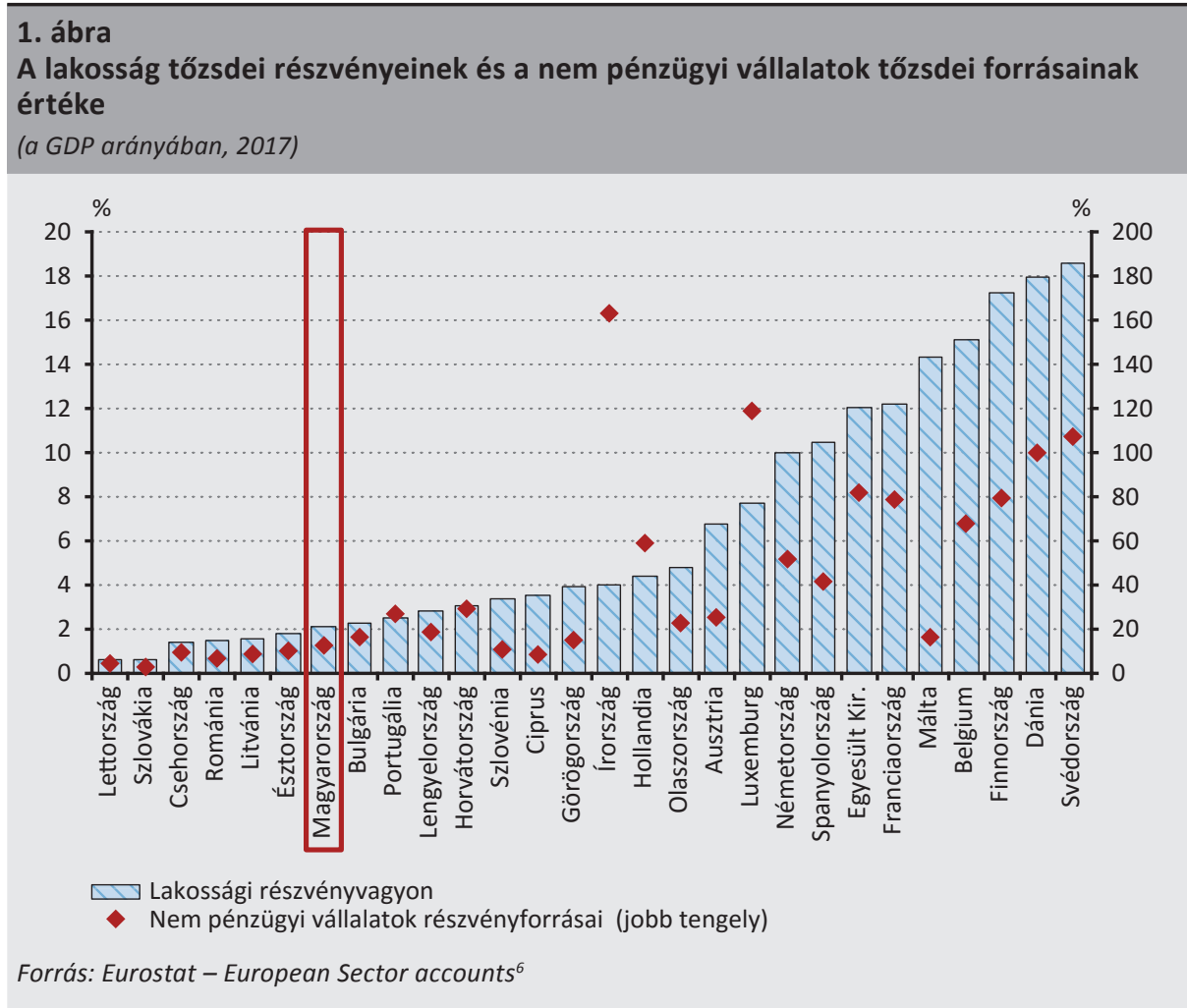

Tanulmányunkban a kockázatos pénzügyi eszközök keresletének tényezői mellett a kínálati oldal szerepét is szeretnénk figyelembe venni, ezért a logisztikus regresszióban két országcsoportot, az aktiv és kevésbé aktiv tökepiaccal rendelkező országokat külön vizsgáljuk (2. ábra). A HFCS-felmérés eredményeinek bemutatásához az európai országokat klaszterelemzéssel csoportosítottuk, a tőkepiaci mélység méréséhez a Worldbank Global Financial Development adatbázisában elérhető tőzsdepiaci jellemzőket vettük alapul (a csoportok létrehozásának módszerét részletesebben a 3. fejezetben mutatjuk be). A klaszterelemzés során létrehozott négy országcsoportból kettőt vontunk be a vizsgálatba, ezek közül az elsőbe tartoznak a kevésbé aktív tőkepiaccal rendelkező országok, többek között Magyarország is. Az aktív tőkepiacú országok csoportjába négy ország került. A kevésbé aktív tőkepiacú országok csoportjában az alacsonyabb kockázatos eszköztartással jellemezhető országok vannak, míg a másik csoport esetén a háztartások legalább 8-10 százalékának van kockázatos pénzügyi eszköze.

\footnotetext{
${ }^{6}$ https://ec.europa.eu/eurostat/web/sector-accounts/overview (Letöltés ideje: 2018. május 20.)
} 


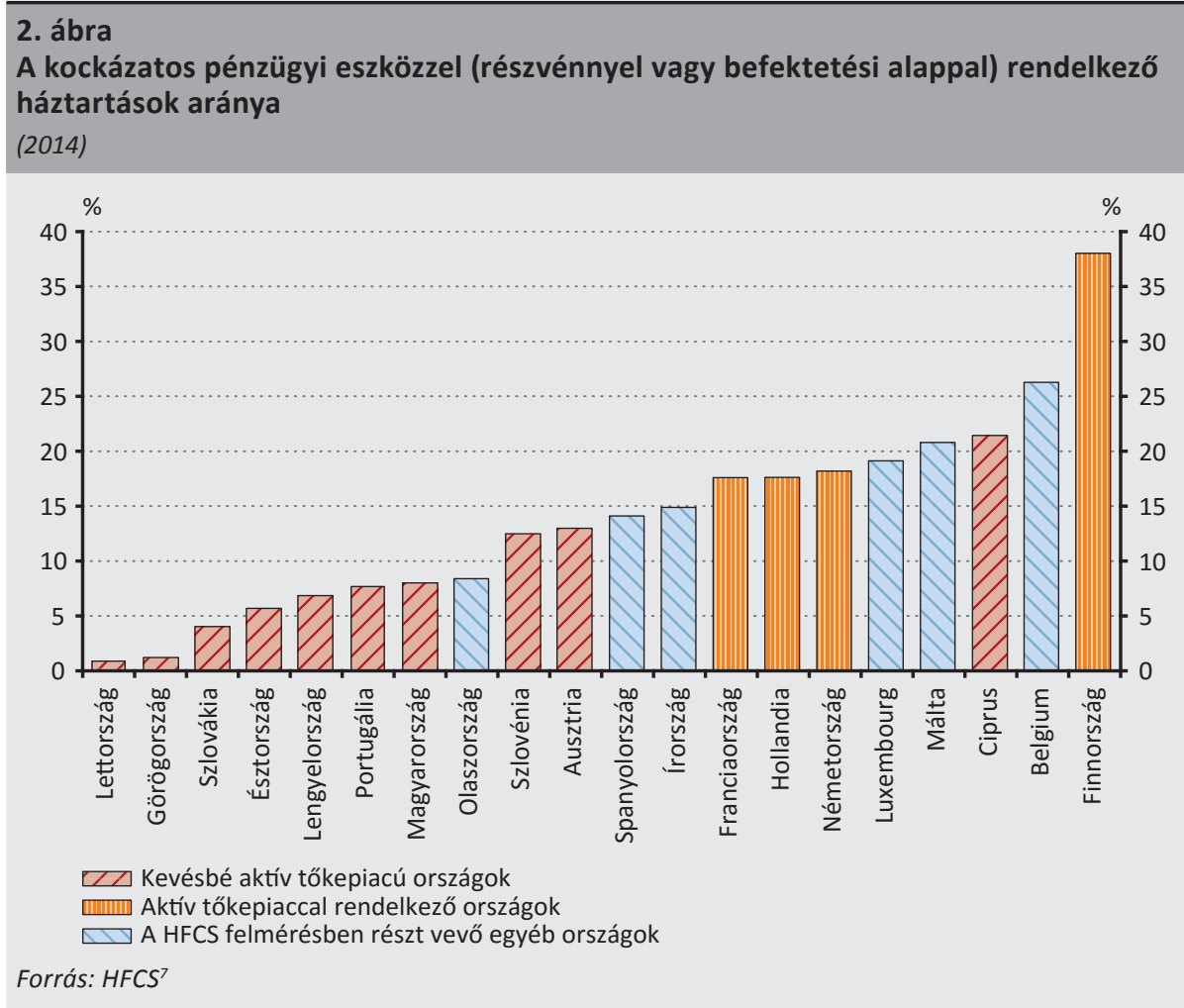

\subsection{A kockázatos eszközök keresletét meghatározó tényezők}

A háztartások biztositási, befektetési jegy-, nyugdíjpénztári és részvényvagyona, azaz valamennyi kockázatos pénzügyi eszköz aránya - az empirikus megfigyelések alapján - az egy före jutó jövedelemmel erős összefüggést mutat (3. ábra). Az európai országokat vizsgálva a szofisztikáltabb befektetési formákban tartott vagyon az egy före jutó jövedelemnél jellemzően gyorsabban emelkedik, azaz az összefüggés nem lineáris. Összességében elmondható, hogy a magasabb jövedelmú országokban a háztartások vagyonuk egyre nagyobb hányadát tartják kockázatosabb eszközökben. E makroadatok alapján fennálló összefüggést vizsgáljuk részletesebben a rendelkezésre álló adatbázis alapján. A HFCS-felmérésből a háztartások pénzügyi eszközeiről részletes bontással rendelkezünk: a bankbetétek mellett a kötvényekről, menedzselt számlákról, részvényekről és befektetési alapokról nyilatkoztatták a háztartásokat, hogy tartanak-e, és ha igen, mennyit. A bankbetétek és a kötvények a jellemzően nem kockázatos eszközök, míg menedzselt számlával a háztartások elenyésző hányada rendelkezik. Emellett külön kategóriaként megjelennek a nyug-

\footnotetext{
${ }^{7}$ https://www.ecb.europa.eu/pub/economic-research/research-networks/html/researcher_hfcn.en.html
} 
díj-megtakarítások is, de a kockázatosság szempontjából - azaz milyen portfólióban tartják a háztartások nyugdíj-megtakarításukat - nem tartalmaz ezekről információt a felmérés. A rendelkezésre álló adatok alapján ezért úgy döntöttünk, hogy az általunk vizsgált kockázatos pénzügyi eszközök körébe a részvényeket és a befektetési alapokat soroljuk, és a következőkben bemutatott leíró statisztikák is ezen eszközök tartóira vonatkoznak.

\section{3. ábra \\ Az európai országok háztartási szektorának részvény-, befektetési jegy- és biztosítási vagyona, illetve az ország egy före eső GDP-je közötti kapcsolat (2016)}

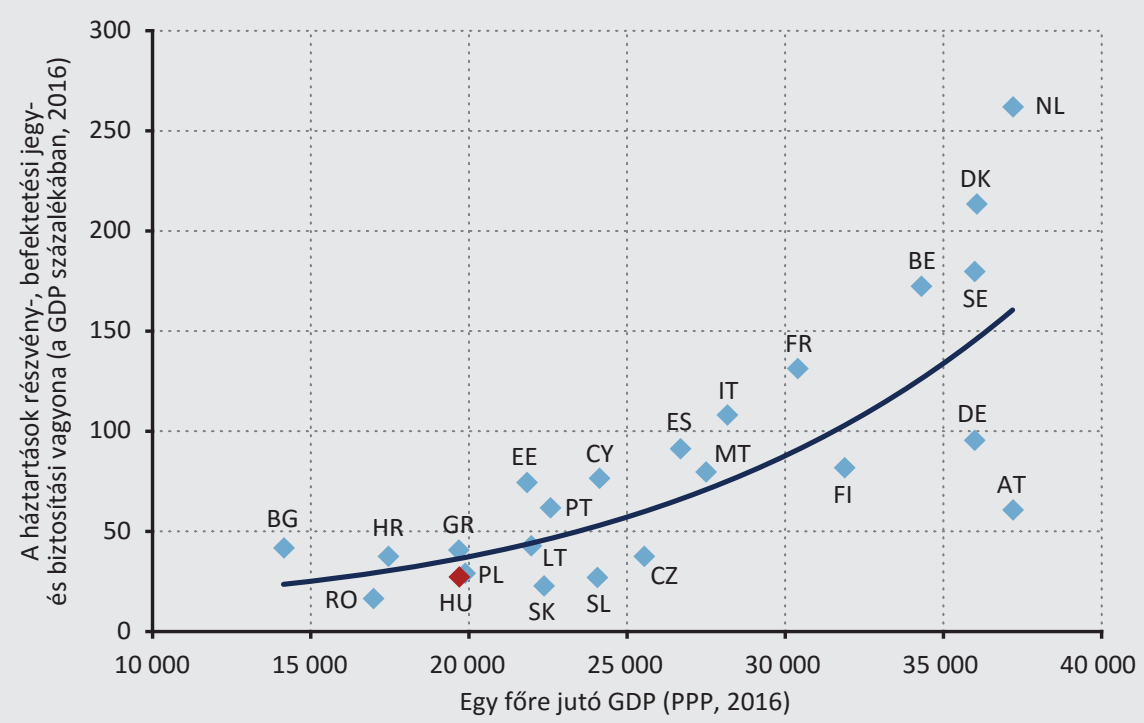

Forrás: Eurostat - European Sector accounts, National Accounts ${ }^{8}$

A HFCS felmérés alátámasztja, hogy a kockázatos eszköz tartásának aránya - nem független a pénzügyi eszközök egyenlötlen megoszlásától - nagyban függ attól, hogy egy háztartás mekkora bruttó vagyonnal, illetve jövedelemmel rendelkezik (4. ábra). A mikroadatbázis alapján a felső kvintilisben a legmagasabb a kockázatos eszközökkel rendelkező háztartások aránya. A vagyon és a jövedelem alapvetően meghatározza, hogy belépnek-e a háztartások a részvénybefektetők piacára. Az alsó vagyoni rétegek (első két ötöd, bruttó vagyon alapján) nagyon alacsony arányban tartanak kockázatos eszközöket. A felsőbb vagyoni rétegek felé haladva a kockázatos eszköz birtoklásának aránya egyre nagyobb mértékben bővül, azaz az összefüggés nem lineáris. Ez az összefüggés az egyedi országok szintjére is igaz: Magyarországon

\footnotetext{
${ }^{8}$ https://ec.europa.eu/eurostat/web/sector-accounts/overview (Letöltés ideje: 2018. május 20.) és https://ec.europa.eu/eurostat/web/national-accounts/overview (Letöltés ideje: 2018. április 13.)
} 
a kockázatos eszközök tartása alacsonyabb szintről és meredekebben növekszik, mint az európai országokban. A kockázatos pénzügyi eszközök jövedelmi kvintilisek szerinti megoszlása ehhez hasonló képet, de összességében ennél kisebb egyenlőtlenséget mutat, így ennek hatását is vizsgáljuk a modellalapú megközelítésben.

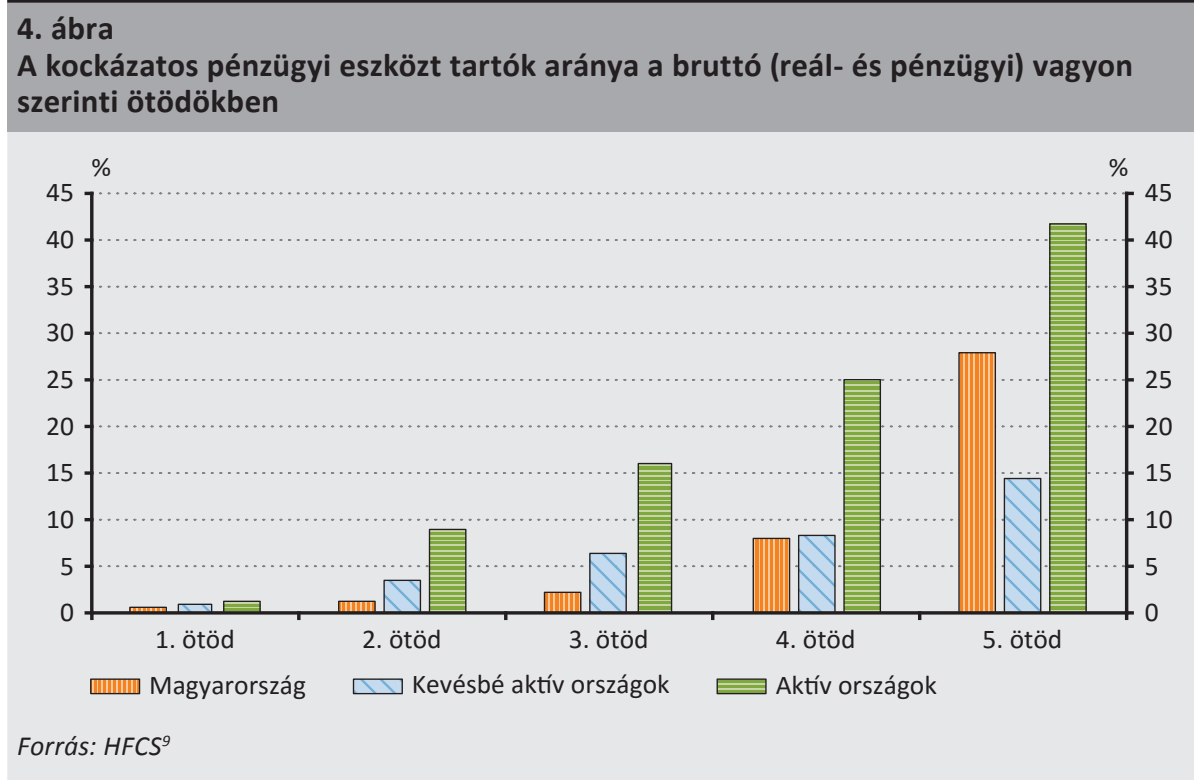

Számos tanulmány rámutatott az iskolai végzettség kockázatos eszközök birtoklásában betöltött szerepére. A háztartásfő (referenciaszemély) ${ }^{10}$ végzettsége a részvénytartás szempontjából azért fontos, mert a magasabb végzettséggel rendelkezők könnyebben hozzájutnak a releváns információkhoz, ezzel a belépési költségeiket csökkentik, így az iskolai végzettség növekedése pozitívan hathat a kockázatos eszköz birtoklására. Haliassos és Bertaut (1995) azt találta, hogy az összes jövedelemcsoport esetében a részvénytartás a magasabb iskolai végzettségű háztartások esetében magasabb. Bertaut (1998) kiterjesztett CAPM-modelljében feltételezi, hogy a részvényekbe történő befektetés függ a háztartások pénzügyi ismereteitől, így végső soron az iskolai végzettségtől.

A HFCS adatai szerint a háztartásfő végzettsége számottevő mértékben meghatározza, hogy az adott háztartás tart-e kockázatos eszközöket (5. ábra). Ez az összefüggés az adatokból is egyértelműen látszik. Az aktív tőkepiacú országok háztartásai annál több részvényt tartanak, minél magasabb végzettségű a háztartásfő. Míg a felsőfokú végzettséggel rendelkező háztartásokban a 30 százalékot közelíti a kockázatos eszközöket tartók aránya, addig középfokú végzettség esetén a háztartásoknak kevesebb,

\footnotetext{
${ }^{9}$ https://www.ecb.europa.eu/pub/economic-research/research-networks/html/researcher_hfcn.en.html

${ }^{10} \mathrm{~A}$ háztartásfő alatt a pénzügyileg leginkább tudatos személyt értjük, aki a HFCS-kérdőív kitöltését végezte.
} 
mint egy ötödének van részvénye vagy befektetési alapja. A valamilyen kockázatos eszközt tartók aránya ettől jóval elmarad a kevésbé aktív tőkepiaccal rendelkező országokban, de a magasabb végzettséggel itt is nő az arány. Meg kell azonban jegyezni, hogy a HFCS-felmérés szerint Magyarországon az alapfokú végzettségűek gyakorlatilag nem fektetnek közvetlenül sem részvénybe, sem befektetési alapba.

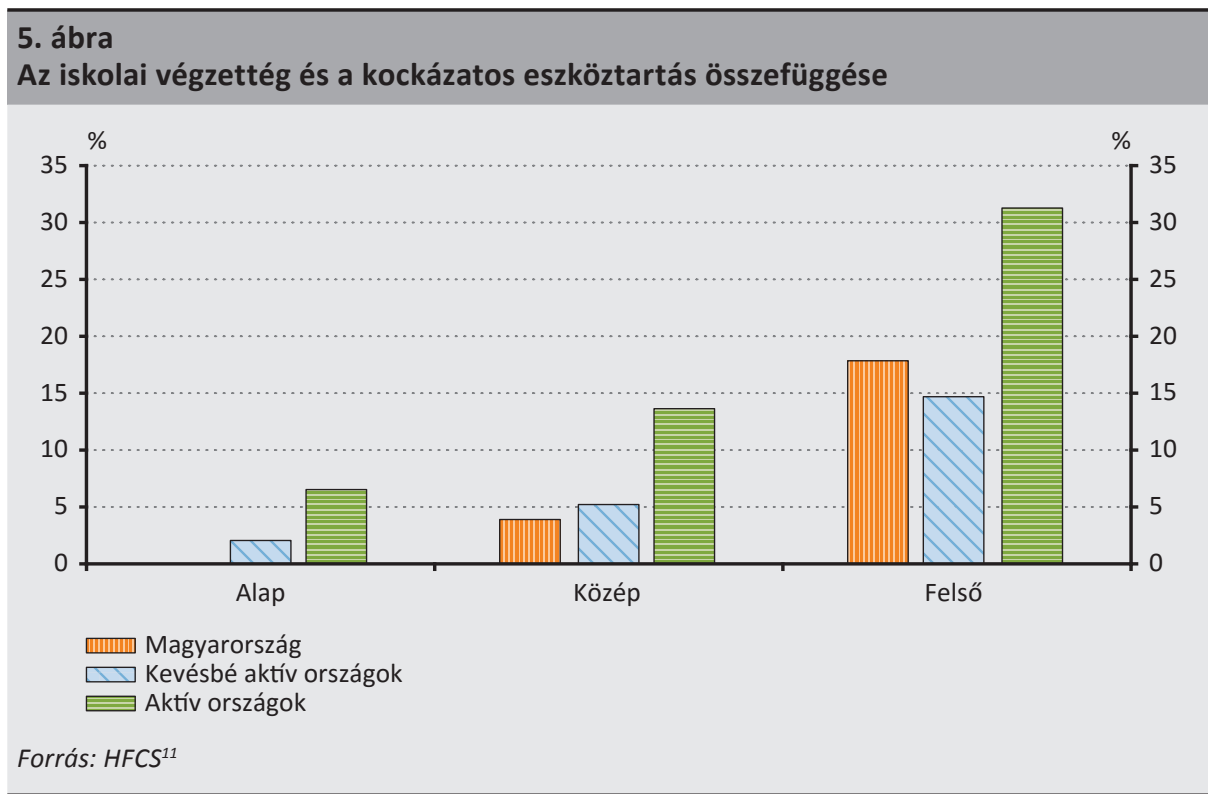

A kockázatos eszközök tartását az iskolai végzettség mellett a háztartásfök foglalkozása is befolyásolhatja. Az emberek szívesen fektetnek olyan cégbe, ahol dolgoznak, mivel jobban ismerik az adott cég működését. Ezt a szakirodalom „sajátrészvény-csapdának" (equity home bias) nevezi (Lewis 1999), mivel ez anélkül növeli a háztartás kockázatait, hogy az észlelné. Diverzifikációs szempontból kevésbé megfelelő az, ha egy háztartás saját munkahelye részvényeibe fektet, mivel pozitív korrelációt eredményez a munkajövedelem és a háztartás által tartott portfólió hozama között. Ugyanakkor Carroll (2001) is megerősítette, hogy a részvényt tartó háztartások jellemzően csak egy, gyakran a munkahelyük részvényébe fektetnek.

A nők általában konzervativabbak befektetéseiket illetően, míg a házasság pozitiv korrelációt mutat a részvénytartással. A nemzetközi empirikus irodalom szerint a háztartásfő neme alapvetően meghatározza, hogy tart-e részvényt az adott háztartás. Női háztartásfő kisebb, férfi háztartásfő esetén nagyobb a gyakorisága a részvénybefektetéseknek. Barber és Odean (2001) például azt találta, hogy a férfiak

\footnotetext{
${ }^{11}$ https://www.ecb.europa.eu/pub/economic-research/research-networks/html/researcher_hfcn.en.html
} 
magabiztosabbak pénzügyi tudásukat illetően, és ezért kockázatosabb portfóliókat tartanak. Emellett házasság (többkeresős háztartás) esetén is gyakoribb a kockázatos eszköz tartása. Ez azzal hozható összefüggésbe, hogy a két különböző helyről kapott jövedelem mérsékli a háztartás kockázatait (Agnew et al. 2003). Barber és Odean (2001) szintén azzal érvel, hogy a házasok közösen hozzák befektetési döntéseiket, és ezáltal csökkentik a nemek közötti különbözőség hatását.

A tanulmányok a külső tényezők közül leginkább a tranzakciós és információs költségek szerepét emelik ki, melyek negativan befolyásolhatják - különösen a szegényebb - háztartások kockázatoseszköz-tartását. Haliassos (2005) szerint a pénzügyi szektor legnagyobb kihívása középtávon az, hogy tudja kezelni a háztartásoknak a kockázatos eszközök piacára való bejutását vagy onnan történő kilépését, nem pedig az, hogy a kockázatos eszközöket már tartó háztartások átsúlyozzák portfóliójukat.

Emellett a hitelfelvételi korlátok jelenléte is jelentösen hátráltatja a háztartások kockázatoseszköz-tartását, és csökkenti a háztartások kockázatos eszközökben tartott portfólió összegét is (Guiso et al. 2001). A hitelfelvételi korlátok jelenlétét jellemzően valamilyen felmérésből származó válaszok segítségével mérik, nem pedig a megtakarítások hiányát tekintik annak. Hasonló hatása lehet annak, ha a háztartás kevés likvid megtakarítással rendelkezik. Növekvő jövedelem és bruttó vagyon esetén ugyanis csökken a likviditáskorlátosság esélye (Boldizsár et al. 2016), amelynek hatása lehet a kockázatos eszközök tartására is.

A háztartások bruttó vagyona mellett a háztartások egyéb jellemzői - például a kockázattal kapcsolatos attitüdjük - is befolyásolják a portfólióallokációs döntéseket. Az elméletek szerint a magasabb kockázatkerülésnek magasabb diverzifikációval kellene párosulnia, aminek köszönhetően adott hozamelvárás mellett alacsonyabb lenne a háztartás által tartott portfólió kockázata. Az empirikus megfigyelések azonban nem ezt igazolják, ugyanis minél inkább kockázatkerülőnek tartja magát egy háztartás, annál kevésbé rendelkezik kockázatos eszközökkel. Mindez arra utalhat, hogy a háztartások többsége nem érti teljes mértékben a diverzifikáció kockázatcsökkentő hatását (Barberis - Huang 2001), illetve hogy a háztartások a várható hozam ellenére is elutasítják a kockázat viselését. Nemcsak a háztartások kockázattal szembeni attitűdje, hanem az általuk észlelt háttérkockázatok (jövedelemmel kapcsolatos háttérkockázat, ingatlanból birtoklásából eredő háttérkockázat) is szerepet játszhatnak a lakosság befektetési döntéseiben (Guiso - Paiella 2008; Cocco 2004; Heaton - Lucas 2000; Zhan 2015; Dong - Jiang 2016; Fratantoni 1998; Wältermann 2011).

A háztartások portfólióallokációjával foglalkozó kutatásokban általában közös, hogy a munkajövedelmet exogénnek tekintik, ami háttér-befektetési kockázatot ${ }^{12}$ generál,

\footnotetext{
${ }^{12}$ E változók egzakt mérése nem lehetséges, ezért ezeket az adatbázisban rendelkezésre álló adatok alapján a 4.1. alfejezetben bemutatott módon számszerűsítettük, és csak a később bemutatásra kerülő modellhez használtuk fel.
} 
és így befolyásolja az eszközök felhalmozását és a portfólió összetételét is (Haliassos 2005). Vagyis a háztartások pénzügyi döntéseiben a háztartásfő munkahelyének és a háztartás jövedelmével kapcsolatban észlelt kockázatoknak jelentős szerepe van. Bár a munkából származó jövedelem - egyes tanulmányok szerint - kockázatos, a munkajövedelem nem korrelál a részvényhozammal, ezért a hozammaximalizálás során a részvényeket a kockázatmentesebb eszközökkel szemben előnyben kellene részesíteni. Az empirikus megfigyelések alapján azonban nem ez figyelhető meg, a munkajövedelem kiesésének már kis valószínúsége is csökkenti a részvénytartást (Cocco et al. 2005). A tanulmányok többsége azt találta, hogy az alacsonyabb jövedelemkockázattal rendelkező háztartások szívesebben vállalnak további kockázatokat. Agnew és társai (2003) azzal érvelnek, hogy a munkahely biztonsága csökkenti a jövedelemmel kapcsolatos kockázatokat, így optimális lenne a kockázati kitettség növelése. Számos tanulmány rámutatott ugyanakkor arra, hogy nem mindegy a foglalkoztatás módja: az, hogy alkalmazotti viszonyról, vagy vállalkozásról van szó. King és Leape (1998), valamint Alessie és társai (2004) azt találták, hogy az egyéni vállalkozók nagyobb valószínúséggel tartanak részvényket. Bertaut és Starr-McCluer (2002) ezzel ellentétben azt mutatta meg, hogy az alkalmazotti viszony pozitívan hat a részvénytartásra, a vállalkozói azonban negatívan.

A háztartásokat a kockázatos pénzügyi eszközökbe történő befektetéstől az ingatlanukkal kapcsolatos kockázatok is visszatartják, különösen a fiatal háztartások érintettek ebben. Egyrészt jellemzően az ő korosztályukat érintő lakásberuházások miatt a fiatal háztartások kevesebb likvid eszközzel rendelkeznek, és nem tudják megfizetni a tőzsdén való részvételhez szükséges költségeket. Másrészt az ingatlan a háztartás vagyonának egyik legfontosabb eszköze, így az ingatlanárak változása jelenős hatással van vagyonukra. Továbbá az ingatlanárak és a kamatok változása a háztartás által igénybe vehető hitel összegét is befolyásolja (Cocco 2004). Vagyis jellemzően a fiatal háztartások vannak kitéve az ingatlanukkal kapcsolatos kockázatoknak.

\section{A kínálati oldal - az országok klaszterelemzéssel történő csoportosítása}

A kínálati oldal szerepének feltárásához a HFCS-ben szereplő országok tőzsdéjének jellemzőit vettük alapul. A szakirodalom alapján a háztartások részvénytartását a kínálati oldal, vagyis az adott ország tőzsdéjének jellemzői, például a tőzsdén jelenlévő cégek száma, kapitalizációjuk, az infrastruktúra szintje és minősége vagy a szükséges információkhoz való hozzájutás költsége is befolyásolják, ezért elemzésünkben ezt a szempontot is figyelembe vesszük. Ez alapján szükségesnek tartjuk, hogy a háztartások kockázatos pénzügyieszköz-tartását vizsgáló regresszióban a kínálati szempontokból leginkább hasonló országokat vonjuk össze. A tőkepiaci mélység méréséhez a Worldbank Global Financial Development adatbázisában elérhető tőzsdepiaci jellemzőket vettük alapul. Ugyanakkor érdemesnek tartjuk felhívni rá a figyelmet, 
hogy a kínálati oldal e mutatók szerinti differenciálása nem tekinthető teljeskörünek a logisztikus regresszióba bevont kockázatos pénzügyi eszközök tekintetében. A HFCS-felmérés alapján a háztartások tőzsdei részvény-, illetve befektetésialap-tartását vizsgáljuk, míg az országok tőkepiaci mélység szerinti klaszterezése három tőzsdepiaci mutató alapján történik (lásd Függelék 6. táblázata). Ezt az egyszerüsítést elsősorban a rendelkezésre álló adatok korlátaiból adódóan kellett megtennünk, ugyanakkor az elgondolás létjogosultságát támasztja alá, hogy jellemzően azokban az országokban, ahol magasabb a háztartások részvénytartása, ott a befektetési alapban tartott vagyonuk is jelentősebb. Emellett Guiso et al. (2003) említi, hogy a befektetési alapoknak fontos szerepe volt a „részvénykultúra” (equity culture) elterjedésében Nyugat-Európában az 1990-es években. Mindezek alapján a tőkepiaci mélység háztartási kockázatoseszköz-tartást meghatározó hatásának figyelembe vételét a következő tőzsdepiaci mutatók alapján tettük meg: tőzsdei kapitalizáció (a listázott részvények értéke), az adott piacon kereskedett részvények piaci értéke a referenciaidőszakban (tranzakciók értéke), illetve a forgalmi arány (turnover ratio), ami annak a mérőszáma, hogy milyen gyakran cserélnek gazdát a részvények. ${ }^{13} \mathrm{Az}$ adatokat vizsgálva elmondható, hogy nagy az országok közötti szórás mind a három mutatót tekintve: valamennyi mutató esetében a szórás 30 körüli értéket vesz fel, míg az értékek terjedelme a néhány százaléktól akár 100 százalék fölötti értékig terjed $^{14}$ (1. táblázat). Ilyen mértékben eltérő tőzsdével rendelkező országok esetében megalapozottnak tűnik a hipotézis, mely szerint több ország háztartásainak részvénytartását vizsgálva szükséges kontrollálni a kínálati oldalra.

\section{1. táblázat}

A HFCS második hullámában szereplő országok tőzsdei mutatóinak leíró statisztikái

\begin{tabular}{l|c|c|c}
\multicolumn{1}{c|}{ Statisztikák } & $\begin{array}{c}\text { Tözsdei } \\
\text { kapitalizáció }\end{array}$ & $\begin{array}{c}\text { Kereskedett } \\
\text { részvények értéke }\end{array}$ & Forgalmi arány \\
\hline Minimum & 4,9 & 0,1 & 0,2 \\
\hline Átlag & 41,9 & 20,8 & 39,3 \\
\hline Maximum & 109,7 & 86,3 & 138,0 \\
\hline Első kvartilis & 14,1 & 0,7 & 6,9 \\
\hline Medián & 34,7 & 9,2 & 32,9 \\
\hline Harmadik kvartilis & 65,1 & 36,7 & 58,3 \\
\hline Interkvartilis terjedelem & 51,0 & 36,0 & 51,5 \\
\hline Szórás & 30,1 & 26,0 & 37,9 \\
\hline
\end{tabular}

Forrás: Worldbank - Global Financial Development Database ${ }^{15}$ alapján számítva

\footnotetext{
${ }^{13}$ Az egyes mutatókból igyekeztünk arra az évre vonatkozót bevonni, amikor az egyes országokban a HFCS felmérés készült, ettől öt ország esetében kellett eltérnünk: Észtország, Finnország, Litvánia és Szlovákia esetében csak egy évvel korábbi adatok álltak rendelkezésre, de Olaszország esetében is egy évvel korábbi adatot használtunk a forgalmi arányra vonatkozóan (EKB 2016a).

${ }^{14}$ Mivel valamennyi mutató százalékban van kifejezve, nem szükséges a relatív szórások számolása; a szórások közvetlenül összehasonlíthatók.

${ }^{15} \mathrm{http}$ ://databank.worldbank.org/data/source/global-financial-development (Letöltés ideje: 2018. június 4.)
} 
A hasonló méretű és forgalmú tőzsdével rendelkező országok csoportosítását klaszterelemzéssel végeztük el, amely az egyik legelterjedtebb módszer egy minta vagy sokaság megfigyeléseinek csoportosítására. A klaszterelemzésnek számos típusa van, jelen tanulmányban az agglomeratív hierarchikus klaszterezést végeztünk el, aminek az az előnye a másik gyakran használt módszer, a K-közép klaszterelemzéssel szemben, hogy a csoportok számát illetően nem szükséges előfeltevésekkel rendelkeznünk. ${ }^{16} \mathrm{~A}$ vizsgált országok egyéb gazdasági jellemzői alapján és a mikroszintű elemzés mintaelemszámát érintő megfontolásokból a klaszterelemzéssel végül négy csoportot hoztunk létre (2. táblázat).

\section{2. táblázat}

A klaszterezés eredményeképpen létrejött országcsoportok

\begin{tabular}{c|c|c|c}
\hline I. & II. & III. & IV. \\
\hline Ausztria & Belgium & Finnország & Olaszország \\
Ciprus & Írország & Franciaország & Spanyolország \\
Észtország & Luxemburg & Németandia \\
Görögország & Málta & & \\
Lengyelország \\
Litvánia
\end{tabular}

A klaszterezéssel kapott négy csoportból az egyik a kevésbé mély tökepiaccal rendelkező országok csoportjaként azonosítható, míg egy másik klaszter az összes mutató alapján mélyebb tőkepiaccal bíró országok csoportjának tekinthető (6. ábra). A csoportosítás eredményének megértéséhez érdemes figyelembe venni a klaszterelemzés dendrogramját - amely az országok osztályozásának sorrendjét mutatja meg -, illetve az eredeti adatokat is. Ezek alapján egyértelmúen elkülönül a III. számú klaszter, amelyben mindhárom mutató alapján fejlett tőzsdével rendelkező országok szerepnek. Ugyanez igaz a Spanyolország és Olaszország alkotta IV. számú klaszterre, de tekintettel e két ország előbbiektől érdemben eltérő gazdasági helyzetére, nem vontuk össze a két csoportot. A II. számú klaszterben olyan országok szerepelnek, amelyekben a tőzsdei kapitalizáció viszonylag magas, de a másik két mutatóban elmaradnak a III. és IV. klaszter országaitól. Elmondható, hogy a II. csoport országaiban jelentős a tőzsde mérete, de aktivitás - amit a másik két mutató ragad

\footnotetext{
${ }^{16}$ A hierarchikus klaszterelemzés egy folyamat, mely kezdetben minden megfigyelést külön klaszternek tekint, és a választott távolságszámítási és összevonási eljárás alapján lépésről lépésre összevonja a legközelebbi csoportokat, melynek eredményeképpen - ha nincs megszakítva - egy klaszter jön létre, amely az összes megfigyelést tartalmazza. A hierarchikus klaszterezés összevonási eljárásaként a teljes láncot (legtávolabbi szomszéd - amely azt a két legközelebbi csoportot vonja össze, melyeknek az egymástól legtávolabbi elemei közti távolság a legkisebb), a távolság számításánál az euklideszi távolságot vettük figyelembe. Bővebben lásd: Kovács (2014).
} 
meg - tekintetében elmaradnak a hasonló GDP-arányos kapitalizációval rendelkező országoktól. Az I. számú klaszter tartalmazza a legtöbb, összesen tíz országot, ezek rendelkeznek a másik három csoporthoz képest fejletlenebb tőzsdével, és ide sorolható Magyarország is. A HFCS kelet-európai országai mellett ide kerültek a balti államok, két mediterrán ország (Görögország és Ciprus), illetve egyetlen nyugat-európai országként Ausztria, amely minden mutatójában érdemben elmarad a III. klaszter országaitól. Mivel a tanulmány egyik célja, hogy magyar vonatkozásban is releváns eredményekkel szolgáljon, a kockázatos eszköztartás mikroszintű elemzése a Magyarországot is tartalmazó I. számú klaszter országaira fókuszál.

\section{6. ábra}

A klaszterelemzés dendrogramja

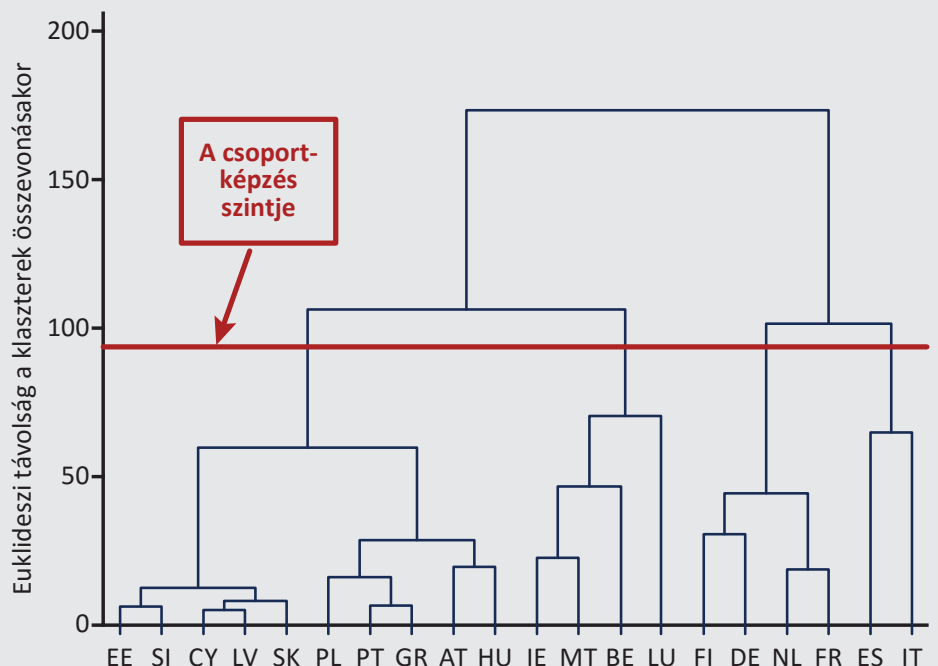

\section{A kockázatos pénzügyi eszköztartás modellezése}

A 2. fejezetben alkalmazott leíró elemzés azt mutatta meg, hogy egy adott szempont szerint hogyan alakul a háztartások részvénytartása, azonban ez az elemzési módszer a kereszthatásokat nem képes kezelni. Könnyen belátható, hogy például a demográfiai helyzet és a jövedelem erősen összefügg, ezért ezek hatását egyszerre érdemes vizsgálni, ha azt szeretnénk megmutatni, hogy az egyes tényezők elkülönített hatása szignifikáns-e a részvény és befektetési alap, vagyis a kockázatos pénzügyi eszközök tartásának szempontjából. Ezért ebben a fejezetben a modellalapú megközelítéssel arra teszünk kísérletet, hogy megbecsüljük azt, hogy a leíró részben 
vizsgált tényezők - a parciális hatásokat tekintve - hogyan hatnak a háztartások fentebb meghatározott kockázatos eszközeinek tartására.

\subsection{Modellspecifikáció}

A kockázatos eszköztartást befolyásoló háztartási tényezők azonosításához logisztikus regressziót alkalmazunk, amelynek fontos előfeltétele az elemzés által megválaszolni kívánt kérdések pontos meghatározása. Egyrészt, ha a háztartások részvénytartását akarjuk vizsgálni, akkor a közvetett részvénytartás mellett a közvetlent is érdemes figyelembe venni. A lakossági részvényvagyon jelentős részét teszi ki a közvetve - befektetési alapokon, nyugdíjpénztárakon, és biztosításokon keresztül - tartott állomány, ugyanakkor Magyarországon a közvetett, pénzügyi intézményrendszeren keresztüli részvénybefektetések állománya is alacsonynak mondható. A közvetett részvénytartás részben a gazdaságpolitikai döntések folyamán kialakított intézményrendszer következménye, azonban nem választható el egyértelműen a közvetlen részvénytartást befolyásoló tényezőktől. A nyugat-európai országok tapasztalatai alapján a nyugdíjalapoknak jelentős szerepe van a részvénytartás elterjesztésében: azokban az országokban, ahol a nyugdíjalapok teljes eszközállománya magas, ott a háztartások részvénytartása is jellemzőbb. A kapcsolat iránya azonban nem egyértelmű, az endogenitás miatt ezért érdemesebb a részvénytartás helyett a közvetett és közvetlen részvénytartást együtt és egyszerre vizsgálni, akár az összes kockázatos eszközt együtt kezelni. A rendelkezésre álló adatbázisban azonban nem minden kockázatos eszközre van adat, így csak a részvénytartás és a befektetési alapba történő befektetés vizsgálható. ${ }^{17}$ Vagyis a modell bináris függő változója abban az esetben veszi fel az 1 értéket, ha a háztartás rendelkezik valamilyen kockázatos eszközzel, azaz tart részvényt vagy befektetési alapot.

Másrészt a kockázatos eszköz tartásában a belépési korlát „megugrása” kulcskérdés: vagyis elösorban azt érdemes vizsgálni, hogy a háztartások tartanak-e kockázatos eszközöket. A portfólióallokációs döntések során a háztartások jellemzői fontosak lehetnek, de nagyobb szerepet játszanak abban, hogy tartanak-e egyáltalán részvényt, mint abban, hogy ha már tartanak kockázatos eszközt, akkor mekkora a kockázatos portfólió része. Haliassos (2005) például rámutatott arra, hogy a háztartások jellemzői (demográfia és egyéb tulajdonságok) jelentősen befolyásolják azt, hogy a háztartások tartanak-e kockázatos eszközt. A kockázatos eszközök aránya és a háztartások jellemzői között azonban már csak gyengébb kapcsolatot talált (hasonlóan Guiso et al. 2003). Ebből kifolyólag érdemesnek tartjuk megvizsgálni, hogy az egyes háztartási jellemzők hogyan befolyásolják - gátolják vagy ösztönzik és mennyire a belépést erre a piacra.

${ }^{17}$ Az általunk is alkalmazott kérdőíves felmérés adatai alapján a befektetési alapokat tartók mintegy harmada részvényalapot tart, miközben elenyésző a kockázatmentesnek tekinthető pénzpiaci alapokat tartók aránya. 
Harmadrészt a kockázatos eszközök tartását a keresleti oldal mellett a tökepiac nem egzakt módon mérhető jellemzői is befolyásolják. Ellentétben a korábban ismertetett tanulmányok eredményeivel, Christelis és társai (2010) azt bizonyították, hogy a kockázatos eszközök tartásában mutatkozó különbségek gyakran nem a háztartások jellemzőiből erednek, hanem a gazdasági környezet eltérése magyarázza a kockázatos eszközök tartását és a kockázatos eszközökbe fektetett összeget. Ezért a vizsgálatba a leíró részben már használt, a klaszterelemzéssel létrehozott két országcsoportot, a mutatók alapján fejlett és kiterjedt tőkepiaccal rendelkező országok és a fejletlenebb tőkepiaccal - alacsonyabb tőzsdei kapitalizációval és aktivitással - rendelkező országok csoportját vontuk be - az utóbbiboz tartozik többek között Magyarország is. Bár elsősorban a magyar háztartások portfólióallokációs döntéseit szeretnénk vizsgálni, a megfelelő elemszám biztosítása érdekében a hasonló tőzsdei jellemzőkkel bíró országokat szükségesnek tartottuk bevonni. Az elemzés során a kockázatos eszköztartást vizsgáló modellt mindkét országcsoportra lefuttattuk azzal a céllal, hogy az egyes tényezők szignifikanciáját, hatásuk mértékét összehasonlítsuk a két eltérő kockázatos eszközkínálattal rendelkező piacon.

A kockázatos eszköztartás modellezése során a háztartások demográfiai, jövedelmi és vagyoni helyzetének hatása mellett a háttérkockázatok hatását vizsgáltuk. A modellezés során azt vizsgáltuk meg, hogy kimutatható-e a háttérkockázatok negatív hatása a részvénytartásra, illetve hogy van-e érdemi eltérés a hatások mértéke között a két országcsoportnál. A szakirodalom segítségével a háttérkockázatok közül Zhan (2015) cikkéhez hasonlóan hármat azonosítottunk: alkalmazotti jövedelem háttérkockázata, ingatlanbirtoklásból eredő háttérkockázat, illetve a vállalkozói jövedelem háttérkockázata. Mivel e változók egzakt mérése nem lehetséges, ezért ezeket az adatbázisban rendelkezésre álló adatok alapján az alábbiakban bemutatott módon számszerűsítettük.

- Alkalmazotti jövedelmi háttérkockázat: a munkaerőpiacnak való jelentős kitettség és az arra jellemző információs aszimmetria bizonytalansági tényezőt jelentenek a háztartások jövedelmében. Ez különösen akkor igaz, ha a háztartás nem rendelkezik egyéb forrásból - például nyugdíjból, ingatlan bérbeadásából, pénzügyi befektetésekből - származó jövedelemmel. Ennek megfelelően azokat a háztartásokat tekintjük kitéve ennek a kockázatnak, amelyeknek minden jövedelme alkalmazotti viszonyból származó bérjövedelem. E tekintetben eltérünk Zhan (2015) megközelítésétől, aki az empirikus tapasztalatok alapján magas munkanélküliséggel jellemezhető szektorokban dolgozó háztartásokat tekintette kitéve ennek a háttérkockázatnak. ${ }^{18}$

${ }^{18}$ Véleményünk szerint csak a foglalkoztatás szektora alapján nehéz megmondani, hogy ki mennyire van kitéve a munkanélküliség kockázatának, és Zhan (2015) sem kapott szignifikáns eredményt erre vonatkozóan. 
- Ingatlanbirtoklásból eredő háttérkockázat: az ingatlanbirtoklás - ahogy az elméleti összefoglalóban is szerepelt - nagymértékben korlátozhatja a rendelkezésre álló likvid jövedelmet, illetve az ingatlanpiacnak való nagyobb kitettségből eredő kockázat visszafoghatja az egyéb piacokon, például a pénzügyi piacokon vállalt kockázatot. Az ingatlanbirtoklás háttérkockázata annál nagyobb, minél nagyobb az ingatlanok aránya a teljes vagyonon belül. A modellben ezért ezt az arányt százalékos formában szerepeltettük.

- Vállalkozói jövedelem háttérkockázata: Heaton és Lucas (2000) tanulmánya alapján azok a háztartások, amelyek jövedelmén belül nagyobb súlyú a vállalkozói jövedelem, kevésbé hajlamosak kockázatos pénzügyi eszközbe fektetni. E háttérkockázat számszerűsítéséhez a Zhan (2015) által is alkalmazott módszert használtuk: a vállalkozói jövedelmet tekintettük a teljes jövedelem arányában.

Emellett a háztartások demográfiai, jövedelmi és vagyoni helyzetének, illetve egyéb jellemzőknek a hatását is vizsgáljuk a kockázatos eszköztartásra. A demográfiai jellemzők közül vizsgáltuk a háztartás méretének, a családi állapotnak és a háztartásfő (referenciaszemély) korának hatását. Külön változóként szerepel a női háztartásfő, ugyanis az adatok és a vonatkozó szakirodalom alapján is az látszik, hogy kevésbé mutatkoznak kockázatkedvelőnek a pénzügyi befektetések terén. Ugyancsak figyelembe vettük a felsőfokú és pénzügyi végzettséget, mivel a magasabb végzettséggel rendelkezők nagyobb valószínúséggel tartanak kockázatos eszközt, illetve a pénzügyi szektorban dolgozók információs tranzakciós költsége alacsonyabb a pénzpiaci termékek esetében. Külön változóként szerepel a háztartás önbevallású befektetési attitűdje, vagyis, hogy mennyire tartja magát kockázatkedvelő befektetőnek. Emellett vizsgáltuk annak a hatását is, hogy a háztartás likviditáskorlátos-e: egy háztartást akkor tekintettünk likviditáskorlátosnak, ha a rendelkezésére álló likvid eszközök nem haladják meg a kéthavi bruttó jövedelmet.

\subsection{A modell eredményei}

A logisztikus regresszió eredményei alapján számos tényező befolyásolja a háztartások kockázatos eszköztartását, ugyanakkor eltérések figyelhetők meg a különbözö aktivitású tőzsdével rendelkező országcsoportok között (3. táblázat). Az elemzés alapján a fő különbség a két megfigyelési csoport között az, hogy a mélyebb (II.) tőkepiaccal rendelkező országokban a demográfiai tényezők hatása több esetben szignifikáns, míg a másik (I.) csoportnál a vagyoni helyzet és a végzettség a fő befolyásoló. Ez összhangban van azzal a megfigyeléssel, hogy a kevésbé aktív tőkepiacú és néhány kivételtől ${ }^{19}$ eltekintve gazdaságilag is fejletlenebb országokban a kockázatos eszköztartás szinte kizárólag a vagyonosabb háztartásokra jellemző.

\footnotetext{
${ }^{19}$ Ausztria például gazdasági fejlettség szempontjából egyértelműen Nyugat-Európához tartozik, de tőzsdepiacának kiterjedtségi szintje alapján a kevésbé aktív csoporthoz tartozik. Ez az outlier jelleg figyelhető meg az 1. ábrán is, ahol az látszik, hogy az egy före jutó GDP alapján Ausztriában több kockázatos eszközt kellene tartania a háztartásoknak.
} 
A jövedelem és a vagyoni helyzet mindkét országcsoportnál jelentös és szignifikáns befolyásoló tényező, ugyanakkor a vagyon kockázatos eszköztartást növelő hatásának mértéke a mélyebb tökepiaccal rendelkező országokban nagyobb. A háztartás jövedelmének 10 százalékos emelkedése átlagosan 0,31 százalékkal növeli a kockázatos eszköztartás valószínúségét, míg a II. országcsoportnál megközelítőleg 0,8 százalékkal. A vagyon hatása ennél jelentősebb és a mélyebb tőkepiaccal rendelkező országoknál érdemben nagyobb mértékben növeli a kockázatos eszközök tartásának valószínűségét, ami ezen eszközök szélesebb körű elterjedtségét támasztja alá. A regresszióban az országok szintjén képzett vagyoni kvintilisek dummy változói szerepelnek, referenciacsoportként a medián - vagyis a harmadik - kvintilis szolgál. Mindkét országcsoportnál az látható, hogy a magasabb kvintilisekben fokozatosan több kockázatos eszközt tartanak a háztartások, de eltérések is kiolvashatóak:

- A Magyarországot is magába foglaló csoportnál az első és második vagyoni kvintilishez való tartozás rendre 6 és 3 százalékkal csökkenti a tartás valószínűségét, ugyanakkor a negyedik kvintilis marginális hatása nem tér el szignifikánsan a harmadik kvintilishez képest. Emellett a legfelső vagyoni csoporthoz való tartozás átlagosan 5 százalékkal növeli a kockázatos eszköztartás valószínúségét.

- A másik országcsoport esetében szintén emelkedés figyelhető meg az egyre magasabb vagyoni kvintiliseket tekintve, de összességében mindegyik kvintilisnél - abszolút értékben - nagyobb a marginális hatások mértéke; az első kvintilishez tartozás 12,4 százalékos csökkenést eredményez a tartás valószínűségében, a második kvintilisnél -6 százalék ez az érték, míg a negyedik és ötödik kvintilisnél rendre 6,3 és 15,5 százalék (a harmadik kvintilishez viszonyítva). 


\section{3. táblázat \\ A logisztikus regresszió eredményei}

\begin{tabular}{|c|c|c|}
\hline & \multicolumn{2}{|c|}{ Átlagos marginális hatások (AMEs) mértéke } \\
\hline & Kevésbé aktív tőkepiac (I.) & Aktívabb tőkepiac (II.) \\
\hline Teljes háztartási jövedelem (log) & $\begin{array}{c}0,031 * * * \\
(0,109)\end{array}$ & $\begin{array}{c}0,078 * * * \\
(0,146)\end{array}$ \\
\hline \multicolumn{3}{|l|}{ Bruttó vagyon (harmadik kvintilis) } \\
\hline Első kvintilis & $\begin{array}{c}-0,056 * * \\
(0,062)\end{array}$ & $\begin{array}{c}-0,124 * * * \\
(0,044)\end{array}$ \\
\hline Második kvintilis & $\begin{array}{c}-0,029 * * * \\
(0,120)\end{array}$ & $\begin{array}{c}-0,06 * * * \\
(0,091)\end{array}$ \\
\hline Negyedik kvintilis & $\begin{array}{c}0,003 \\
(0,173) \\
\end{array}$ & $\begin{array}{c}0,063 * * * \\
(0,207)\end{array}$ \\
\hline Ötödik kvintilis & $\begin{array}{c}0,049 * * * \\
(0,284)\end{array}$ & $\begin{array}{c}0,155^{* * *} \\
(0,367)\end{array}$ \\
\hline Felsőfokú végzettség & $\begin{array}{c}0,049 * * * \\
(0,208)\end{array}$ & $\begin{array}{c}0,056 * * * \\
(0,128)\end{array}$ \\
\hline Pénzügyi szektorban dolgozó & $\begin{array}{c}0,055^{* * *} * \\
(0,506)\end{array}$ & $\begin{array}{c}0,096 * * * \\
(0,403)\end{array}$ \\
\hline
\end{tabular}

Kockázatvállalás befektetéseknél

(nem vállal kockázatot)

\begin{tabular}{c|c|c}
\hline \multicolumn{1}{c|}{ Átlagos } & $0,08^{* * *}$ & $0,137^{* * *}$ \\
& $(0,880)$ & $(1,250)$ \\
\hline Átlag feletti & $0,134^{* * *}$ & $0,238^{* * *}$ \\
& $(0,881)$ & $(1,030)$ \\
\hline Kiemelkedő & $0,088^{* *}$ & $0,156^{*}$ \\
& $(0,301)$ & $(0,220)$ \\
\hline Gyermekek száma & $-0,006$ & $-0,017^{* *}$ \\
& $(0,065)$ & $(0,037)$ \\
\hline Női háztartásfó & $-0,018^{* *}$ & $-0,033^{* * *}$ \\
& $(0,072)$ & $(0,060)$ \\
\hline Likviditáskorlát & $-0,021^{* * *}$ & $-0,058^{* * *}$ \\
& $(0,069)$ & $(0,053)$ \\
\hline Kor & 0,000 & 0,000 \\
& $(0,004)$ & $(0,003)$ \\
\hline Munkaerőpiaci kitettség & $-0,023^{*}$ & $-0,123^{* * *}$ \\
& $(0,128)$ & $(0,090)$ \\
\hline Vállalkozásból származó jövedelem & $-0,0005^{* * *}$ & $-0,0013^{* * *}$ \\
& $(0,001)$ & $(0,002)$ \\
\hline Lakhatási célú ingatlan birtoklása & $-0,031^{* *}$ & $-0,047^{* *}$ \\
& $(0,093)$ & $(0,092)$ \\
\hline Mintaelemszám & 23430 & 21200 \\
\hline
\end{tabular}

Megjegyzés: A vagyoni kvintilisek esetén a harmadik kvintilis, a kockázatvállalási attitüd esetében $a$ „nem vállal kockázatot” a referenciacsoport. Az átlagos marginális hatások alatt zárójelben a robusztus standard hibák találhatók. * $p<0,05 ;{ }^{*} p<0,01 ; * * * p<0,001$ 
A fentiekből két következtetést vonhatunk le. Egyrészt a mélyebb tőkepiaccal rendelkező országokban kvintilisenként fokozatosabban emelkedik a tartók aránya, amiből - a vonatkozó leíró statisztikával együtt - arra következtethetünk, hogy a relatíve kisebb vagyonnal rendelkező háztartásoknál jellemzőbb a részvény és befektetési alap tartása, mint a másik országcsoportban. Másrészt a kevésbé kiterjedt tőkepiacú országok esetében kiemelkedik a legfelső vagyoni kvintilis elválása a többitől. A 4. táblázat szemlélteti, hogy a magasabb vagyoni kvintilisekben egyre nagyobb a kockázatos eszközt tartók aránya. Míg a mélyebb tőkepiacú országokban fokozatosan emelkedik ez az arány, addig a másik országcsoportban jelentősebb megugrás figyelhető meg az ötödik kvintilisnél. Ez Magyarországra kiemelten igaz: míg a negyedik kvintilisben a tartók aránya csak 13-szoros az első kvintilishez képest, addig az ötödik kvintilisben közel 46-szoros. De a fokozatosság hiányára utal az is, hogy Magyarországon a második és harmadik kvintilis, az egyéb kevésbé aktív tőkepiacú országoknál pedig a harmadik és negyedik kvintilis között nincs - az aktívabbak csoportjához hasonló - jelentősebb különbség (ami összhangban van azzal, hogy a regresszióban az I. országcsoportnál nem szignifikáns a negyedik kvintilis hatása a mediánhoz képest). Ez alapján arra következtethetünk, hogy ezen országokban a kockázatos eszköztartás koncentráltabb, főleg a legvagyonosabb háztartásokra jellemző.

\section{4. táblázat}

Az egyes vagyoni kvintilisekben a kockázatos eszközt tartók aránya az első vagyoni kvintilishez képest

\begin{tabular}{c|c|c|c} 
Vagyon kvintilis & Magyarország & Kevésbé aktív országok & Aktív országok \\
\hline I. & 1 & 1 & 1 \\
\hline II. & 2,0 & 3,4 & 7,9 \\
\hline III. & 3,9 & 6,1 & 14,2 \\
\hline IV. & 13,0 & 7,7 & 22,4 \\
\hline V. & 45,9 & 13,4 & 37,1 \\
\hline
\end{tabular}

A vagyon és jövedelem szintje mellett fontos befolyásoló tényező a likviditási korlát jelenléte is. A modellben azt vizsgáltuk, milyen hatása van annak, ha a háztartás likvid - itt a bankszámlán, látra szóló és lekötött betétben tartott - eszközei kevesebb, mint annak kéthavi bruttó jövedelmét teszik ki. A regresszió alapján ez az állapot a kiterjedtebb tőzsdével rendelkező országokban közel 6, míg a másik országcsoportban 2,1 százalékkal csökkenti a kockázatos eszköztartás valószínúségét. Ez arra utal, hogy aki nem tud likvid formában, óvatossági megfontolásokból félretenni, az kevésbé valószínű, hogy megfontolja a részvényt vagy a befektetési alapot mint lehetséges megtakarítási formát. 
Az iskolai végzettség szintje és a pénzügyi szektorban való foglalkoztatottság szintén erősen pozitiv és szignifikáns hatással van a kockázatos eszköztartás valószínüségére. A pénzügyi befektetésekhez szükséges információszerzés tranzakciós költségeit - az empíria és az elmélet alapján is - csökkentő felsőfokú végzettség a logisztikus regresszió szerint az aktív és kevésbé aktív tőkepiacú országoknál rendre 5,6 és 4,9 százalékkal növeli a kockázatos eszköztartás valószínűségét. A szintén releváns információk könnyebb megszerzését segítő pénzügyi szektorbeli elhelyezkedés hasonló mértékben növeli a háztartások kockázatos eszköztartását (9,6 és 5,5 százalékos emelkedés).

A demográfiai jellemzők közül elsősorban a gyermekek száma és a háztartásfő neme befolyásolja a kockázatos eszköztartást. A gyermeknevelés jelentős mértékú pénzügyi eszközöket köt le egy háztartásnál, így várhatóan csökkenti a részvény és befektetési alap tartásának valószínűségét. Ez a negatív hatás $(0,6$, illetve 1,7 százalék követő csökkenés) látszik mindkét vizsgált országcsoportnál, ugyanakkor a kevésbé aktív tőkepiacú országoknál nem szignifikáns. Ezzel szemben a női háztartásfőnek mindkét csoportban szignifikánsan negatív hatása van a kockázatos eszköztartás valószínűségére: az I. és II. országcsoportban rendre 1,8 és 3,3 százalékkal csökken a tartás valószínűsége. Emellett vizsgáltuk még a családi állapot és a kor hatását, de nem találtunk szignifikáns kapcsolatot. Míg a kevésbé kiterjedt tőzsdével rendelkező országoknál a kor hatása a leíró statisztikák alapján sem volt érdemi, addig a másik országcsoportnál úgy tűnt, hogy a korral nő a kockázatos eszköztartás, de ezt a - parciális hatásokat vizsgáló - modell nem támasztotta alá. Összességében elmondható, hogy a kevésbé aktív tőkepiacú országokban a demográfiai jellemzők szerepe kisebb, a modell alapján csak a háztartásfő neme befolyásol. Ez összhangban van azzal a korábbi megállapítással, hogy ezekben az országokban a vagyoni helyzet és a végzettség a domináns befolyásoló tényező a kockázatos eszköztartásban.

A modell alátámasztja azt a feltevést, hogy a háttérkockázatok szerepet játszanak abban, hogy a háztartások kockázatos eszköztartása alacsonyabb az elméletek által optimálisnak tartott szintnél. Mindhárom vizsgált háttérkockázati mutató szignifikánsan csökkenti a részvény és befektetési alap tartásának valószínűségét mindkét országcsoportban, a hatásukban jelentős különbség a munkaerőpiaci kitettségnél figyelhető meg. Amennyiben egy háztartás teljes mértékben rá van utalva a munkabérből származó jövedelemre, az az I. országcsoportban átlagosan 2,3, a II. csoportban 12,3 százalékkal csökkenti a kockázatos eszköztartás valószínúségét. Ez a jelentős eltérés vélhetően a kockázatos eszközök II. csoportbeli szélesebb körű elterjedésével magyarázható: a kevésbé aktív tőkepiaccal rendelkező országokban azok sem tartanak érdemben több részvényt, akik egyébként rendelkeznek egyéb forrásból származó jövedelemmel, ezért nem olyan éles a különbség. Ezzel szemben mélyebb tőkepiacú országokban - amelyek egyben gazdaságilag fejlettebbek is - feltehetően kevesebben vannak, akik csak munkabérből élnek, és többségében 
az alacsonyabb jövedelmi kvintilisekhez tartoznak. A lakhatási célú ingatlan birtoklásából eredő háttérkockázat és kiszorítási hatás is kimutatható a modellből: ezek a háztartások érdemben kisebb valószínűséggel tartanak kockázatos eszközöket (a hatás az I. és II. országcsoportban rendre -3,1 és $-4,7$ százalék). Az egyéb jövedelmeknél - az empíria alapján - volatilisebb vállalkozásból származó jövedelem szintén negatívan hat a részvénytartásra. Amennyiben a teljes háztartási jövedelmen belül a vállalkozói jövedelem súlya 1 százalékponttal emelkedik, az a Magyarországot is tartalmazó országcsoportoknál 0,05, a másik kategóriában pedig 0,13 százalékkal csökkenti a kockázatos eszköztartás valószínűségét. Ugyanakkor érdemes megjegyezni, hogy valamennyi háttérkockázati mutató esetében viszonylag alacsony marginális hatást mutatott ki a modell, ami vélhetően a vizsgált csoport - például a csak munkavállalói jövedelemből élők - heterogén jellegével magyarázható (főleg az alacsonyabb tőkepiaci aktivitással jellemezhető országokban).

A háztartások vagyoni, jövedelmi és demográfiai jellemzőire való kontrollálás után is szignifikáns hatása van a háztartásfö befektetési attitüdjének. Az önmagukat kockázatkerülőnek tekintő háztartások szolgálnak referenciacsoportként, ezen felül három lehetőség közül választhattak a megkérdezettek: átlagos, átlag feletti és kiemelkedően kockázatvállaló. A két vizsgált országcsoport esetében eltérő mértékű hatások mellett hasonló mintázat figyelhető meg; az I. csoportban az átlagos kockázatot vállalónál 8, az átlag feletti esetében pedig 13,4 százalékkal emelkedik a kockázatos eszköztartás valószínűsége. Ugyanakkor érdekes eredmény, a legfelső kategóriához tartozás kisebb mértékben növeli a részvénytartás valószínűségét, mint az átlag feletti, mindkét országcsoportban. Ez az ellentmondás többek között származhat abból, hogy a háztartások csak kisebb részére jellemző, hogy a kiemelkedő kockázat (és az ebből várható kiemelt hozam elérése) miatt tartana részvényt - e szempontból jobb befektetési alternatívát jelentenek a kockázati tőkebefektetések, akár startupokat célozva.

\section{Következtetések}

A tanulmányunk a háztartások kockázatos pénzügyi eszköztartását és az azt meghatározó tényezőket vizsgálja meg. A háztartások vagyonán belül a kockázatosabb eszközök aránya a gazdaság fejlettségével erős összefüggést mutat. Ugyanakkor több tanulmány rámutatott arra, hogy még a fejlett országokban is alacsonynak tekinthető a részvényt tartó háztartások aránya, mivel a háztartások nem az elméleteknek megfelelően diverzifikálják portfóliójukat. A téma kutatását a vagyonra vonatkozó, a háztartások egyedi jellemzőit tartalmazó, a magyar háztartásokat is magába foglaló kérdőíves felmérés tette lehetővé (HFCS).

Tanulmányunkban arra kerestük a választ, hogy milyen tényezőktől függ, hogy egy háztartás tart-e kockázatos pénzügyi eszközt (részvényt vagy befektetési alapot). 
A keresleti tényezők vizsgálata mellett a tőkepiaci mélység szerint is differenciáltunk, így külön vizsgáltuk az aktív és a kevésbé aktív tőkepiaccal rendelkező országokat. Az elemzés első felében szereplő leíró elemzést kiegészítő logisztikus regresszió lehetővé tette, hogy meghatározzuk egy adott tényező részvénytartásra gyakorolt parciális hatását.

Elemzésünk legfontosabb üzenetei a következők:

- A háztartások tőzsdei részvénytartása és a vállalatok részvényben történő finanszírozása között erős kapcsolat mutatható ki. A nagyobb egy főre eső GDP-vel rendelkező országokban a vállalati szektor akár a GDP értékét is meghaladó részvényforrásokkal is rendelkezhet, míg Magyarországon ennek mértéke csupán a GDP 20 százalékát teszi ki.

- A kockázatos eszköztartás nagyban függ attól, hogy egy háztartás mekkora vagyonnal, illetve jövedelemmel rendelkezik. A vizsgálatba bevont országokat több csoportra bontottuk attól függően, milyen fontos szerepet tölt be a tőzsde a finanszírozásban. Az aktív tőzsdepiacú országcsoportban ugyanakkor a kisebb vagyonnal (jövedelemmel) rendelkező háztartások is érdemben tartanak kockázatos eszközt, míg a másik, Magyarországot is magába foglaló országcsoportban ez sokkal kevésbé jellemző (ami vélhetően az alacsonyabb átlagos jövedelemmel áll összefüggésben).

- Az aktívabb tőkepiacú, döntően nyugat-európai országokban a lakosság jóval nagyobb arányban tart közvetlenül, mint közvetetten részvényt, míg a kevésbé fejlett tőkepiaccal rendelkező országokban a közvetett részvénytartás elterjedtebb.

- A likviditási korlát jelenléte is fontos befolyásoló tényező: aki nem tud likvid formában, óvatossági megfontolásokból félretenni, az kevésbé valószínű, hogy megfontolja a részvényt vagy a befektetési alapot mint lehetséges megtakarítási formát. Ezzel szemben, az eredményeink alapján a hitelezésnek nincs szerepe a kockázatos eszközök tartásában.

- A végzettség és bizonyos gazdasági (például pénzügyi) szektorokban való foglalkoztatottság szintén erősen pozitív hatással van a kockázatos eszköztartás valószínúségére. Mivel a kereszthatások kiszűrése miatt ez a megállapítás a jövedelemtől független, a pénzügyi kultúra fejlesztését célzó intézkedések várhatóan pozitívan befolyásolják a háztartások kockázatos pénzügyi eszköz tartását is.

- A demográfiai jellemzők (gyermekek száma, családi állapot, kor) szerepe kisebb a kockázatos eszköztartásban, ami fokozottan igaz a kevésbé aktív tőkepiaccal rendelkező országokra. Mindez összhangban van azzal a megállapítással, hogy ezekben az országokban a vagyoni és jövedelmi helyzet a domináns befolyásoló tényező. 
- A nagyfokú munkaerő- és ingatlanpiaci kitettség, illetve a munkabérnél volatilisebbnek tekinthető vállalkozói jövedelem nagyobb súlya negatívan befolyásolja a kockázatos pénzügyi eszközök tartását. A szakirodalom szerint ezek nem, vagy csak nehezen számszerúsíthető kockázatok, amelyekkel azonban az egyénnek számolnia kell befektetési döntései során, ezért összességében mérsékelhetik a háztartások kockázatos pénzügyi eszközeinek arányát.

- A fentiek mellett jelentősen befolyásolja a háztartások kockázatos eszköztartását az önbevalláson alapuló befektetési attitűd, vagyis, hogy egy háztartás mennyire tartja magát kockázatvállalónak. A kockázatkerülő háztartások szignifikánsan alacsonyabb mértékben tartanak kockázatos eszközöket mind az aktív, mind a kevésbé aktív tőkepiaccal rendelkező országokban.

\section{Felhasznált irodalom}

Agnew, J. - Balduzzi, P. - Sunden, A. (2003): Portfolio choice and trading in a large 401 (k) plan. The American Economic Review, 93(1): 193-215. https://doi.org/10.1257/ 000282803321455223

Alessie, R. - Hochguertel, S.- Soest, A. (2004): Ownership of stocks and mutual funds: a panel data analysis. The Review of Economics and Statistics, 86(3): 783-796. https:// doi.org/10.1162/0034653041811761

Barber, B. - Odean, T. (2001): Boys will be boys: Gender, overconfidence, and common stock investment. Quarterly Journal of Economics, 116(1): 261-292. https://doi.org/10.1162/ 003355301556400

Barberis, N. - Huang, M. (2001): Mental accounting, loss aversion, and individual stock returns. The Journal of Finance, 56(4): 1247-1292. https://doi.org/10.1111/0022-1082. 00367

Bawa, V. - Lindenberg, E. (1977): Capital market equilibrium in a mean-lower partial moment framework. Journal of Financial Economics, 5(2): 189-200. https://doi.org/10.1016/0304405X(77)90017-4

Benatzi, S. - Thaler, R. (1995): Myopic loss aversion and the equity premium puzzle. The Quarterly Journal of Economics, 110(1): 73-92. https://doi.org/10.2307/2118511

Bertaut, C. (1998): Stockholding behavior of US households: Evidence from the 1983-1989 survey of consumer finances. Review of Economics and Statistics, 80(2): 263-275. https:// doi.org/10.1162/003465398557500 
Bertaut, C. - Starr-McCluer, M. (2002): Household portfolios in the United States. In: Guiso. L. - Haliassos, M. - Jappelli, T. (Eds.), Household Portfolios, pp. 181-217. Cambridge, MA: The MIT Press.

Bodie, Z. - Merton, R. - Samuelson, W. (1992): Labor supply flexibility and portfolio choice in a life cycle model. Journal of Economic Dynamics and Control, 16(3-4): 427-449. https:// doi.org/10.1016/0165-1889(92)90044-F

Boldizsár Anna - Kékesi Zsuzsa - Kóczián Balázs - Sisak Balázs (2016): A magyar háztartások vagyoni helyzete a HFCS felmérés alapján. Hitelintézeti Szemle, 15(4): 115-150. http:// www.hitelintezetiszemle.hu/letoltes/boldizsar-anna-kekesi-zsuzsa-koczian-balazs-sisakbalazs.pdf

Carroll, C. D. (2001): Portfolios of the Rich. In: Guiso. L. - Haliassos, M. - Jappelli, T. (Eds.): Household Portfolios, Cambridge, MA: MIT Press.

Christelis, D. - Georgarakos, D. - Haliassos, M. (2010): Differences in portfolios across countries: Economic environment versus household characteristics. CEPR Discussion Papers (8017).

Cocco, J. (2004): Portfolio Choice in the Presence of Housing. IFA Working Paper 410, London Business School.

Cocco, J. - Gomes, F. - Maenhout, P. (2005): Consumption and portfolio choice over the life cycle. Review of Financial Studies, 18(2): 491-533. https://doi.org/10.1093/rfs/hhi017

Dong, H. - Jiang, J. (2016): Risky Asset Holding and Labour Income Risk: Evidence from Italian Households. Lund University School of Economics and Management, May 25th.

EKB (2016a): The Household Finance and Consumption Survey: results from the second wave. Statistics Paper Series, Európai Központi Bank. https://www.ecb.europa.eu/pub/ pdf/scpsps/ecbsp18.en.pdf. Letöltés ideje: 2018. június 1.

EKB (2016b): The Household Finance and Consumption Survey: methodological report for the second wave. Statistics Paper Series, Európai Központi Bank. https://www.ecb.europa. eu/pub/pdf/scpsps/ecbsp17.en.pdf. Letöltés ideje: 2018. június 1.

EKB (2018): Is the top tail of the wealth distribution the missing link between the Household Finance and Consumption Survey and national accounts? Working Paper Series, Európai Központi Bank. https://www.ecb.europa.eu/pub/pdf/scpwps/ecb.wp2187.en.pdf. Letöltés ideje: 2018. november 7.

Fratantoni, M. C. (1998): Homeownership and Investment in Risky Assets. Journal of Urban Economics, 44(1): 27-42. https://doi.org/10.1006/juec.1997.2058 
Gollier, C. (2001): The Economics of Risk and Time. Cambridge, MA: MIT Press. https://doi. org/10.7551/mitpress/2622.001.0001

Guiso. L. - Haliassos, M. - Jappelli, T. (2001): Household Portfolios. Cambridge, MA: MIT Press.

Guiso. L. - Haliassos, M. - Jappelli, T. (2003): Stockholding in Europe: Where Do We Stand and Where Do We Go? Economic Policy, 18(36): 117-164.

Guiso, L. - Paiella, M. (2008): Risk aversion, wealth, and background risk. Journal of the European Economic Association, 6(6): 1109-1150. https://doi.org/10.1162/ JEEA.2008.6.6.1109

Haliassos, M. (2005): Household Demographics and the Composition of Savings. In: Heise, M. - Wieland, V. (eds.), Capital Markets in the Long Term: Demography, Economic Development, and Funded Pension Systems, Frankfurt: CFS and Allianz, pp. 83-106.

Haliassos, M. - Bertaut, C. (1995): Why do so few hold stocks? The Economic Journal, 105(432): 1110-1129. https://doi.org/10.2307/2235407

Harlow, W. (1991): Asset allocation in a downside risk framework. Financial Analysts Journal, 47(5): 28-40. https://doi.org/10.2469/faj.v47.n5.28

Heaton, J. - Lucas, D. (2000): Portfolio choice in the presence of background risk. The Economic Journal, 110(460): 1-26. https://doi.org/10.1111/1468-0297.00488

Kahneman, D. - Tversky, A. (1979): Prospect theory: An analysis of decision under risk. Econometrica, 47(2): 263-292. https://doi.org/10.2307/1914185

Kahneman, D. - Tversky, A. (1984): Choices, values, and frames. American Psychologist, 39(4): 341-350. https://doi.org/10.1037/0003-066X.39.4.341

King, M. - Leape, J. (1987): Asset accumulation, information, and the life cycle. NBER Working Paper (2392).

King, M. - Leape, J. (1998): Wealth and portfolio composition: Theory and evidence. Journal of Public Economics, 69(2): 155-193. https://doi.org/10.1016/S0047-2727(98)00027-9

Kovács Erzsébet (2014): Többváltozós adatelemzés. Budapesti Corvinus Egyetem, Typotex.

Lewis, K. (1999): Trying to Explain Home Equity Bias in Equities and Consumption Consumption. Journal of Economic Literature, 37(2): 571-608. https://doi.org/10.1257/jel.37.2.571

Lintner, J. (1965): The valuation of risk assets and the selection of risky investments in stock portfolios and capital budgets. The Review of Economics and Statistics, 47(1): 13-37. https://doi.org/10.2307/1924119 
Markowitz, H. (1952): Portfolio selection. The Journal of Finance, 7(1): 77-91. https://doi. org/10.2307/2975974

Paxson, C. (1990): Borrowing constraints and portfolio choice. The Quarterly Journal of Economics, 105(2): 535-543. https://doi.org/10.2307/2937799

Sharpe, W. (1964): Capital asset prices: A theory of market equilibrium under conditions of risk. The Journal of Finance, 19(3): 425-442. https://doi.org/10.2307/2977928

Zhan, J. C. (2015): Who holds risky assets and how much? An empirical study based on the HFCS data. Empirica, 42(2): 323-370. https://doi.org/10.1007/s10663-015-9295-1

Wältermann, M. (2011): Household Portfolios and Volatility: Evidence from Dutch Households over Booms and Bust. University of Zurich, Department of Economics, Bachelor of Arts $\mathrm{UZH}$ (in Economics). 


\section{Függelék}

\section{5. táblázat}

\section{A HFCS második hullámának fő jellemzői}

\begin{tabular}{|c|c|c|}
\hline Ország & Mintaelemszám & Adatfelvétel éve \\
\hline Belgium & 2238 & 2014 \\
\hline Németország & 4461 & 2014 \\
\hline Észtország & 2220 & 2013 \\
\hline Írország & 5419 & 2013 \\
\hline Görögország & 3003 & 2014 \\
\hline Spanyolország & 6106 & 2011 \\
\hline Franciaország & 12035 & 2014 \\
\hline Olaszország & 8156 & 2014 \\
\hline Ciprus & 1289 & 2014 \\
\hline Lettország & 1202 & 2014 \\
\hline Luxembourg & 1601 & 2014 \\
\hline Magyarország & 6207 & 2014 \\
\hline Málta & 999 & 2013 \\
\hline Hollandia & 1284 & 2013 \\
\hline Ausztria & 2997 & 2014 \\
\hline Lengyelország & 3455 & 2013 \\
\hline Portugália & 6207 & 2013 \\
\hline Szlovénia & 2553 & 2014 \\
\hline Szlovákia & 2135 & 2014 \\
\hline Finnország & 11030 & 2013 \\
\hline
\end{tabular}




\section{6. táblázat}

\section{A klaszterelemzéshez használt tőzsdei mutatók}

\begin{tabular}{|c|c|c|c|c|}
\hline Klaszter sorszáma & Ország & $\begin{array}{c}\text { Tőzsdei } \\
\text { kapitalizáció } \\
\text { (GDP\%) }\end{array}$ & $\begin{array}{c}\text { Kereskedett } \\
\text { részvények értéke } \\
\text { (GDP\%) }\end{array}$ & Forgalmi arány (\%) \\
\hline \multirow{10}{*}{ I. } & Ausztria & 24,5 & 6,3 & 26,8 \\
\hline & Ciprus & 13,3 & 0,2 & 1,8 \\
\hline & Észtország & 8,5 & 0,9 & 9,4 \\
\hline & Görögország & 29,1 & 12,1 & 48,1 \\
\hline & Lengyelország & 37,0 & 12,9 & 37,4 \\
\hline & Litvánia & 9,2 & 0,5 & 4,4 \\
\hline & Magyarország & 12,1 & 6,3 & 42,1 \\
\hline & Portugália & 32,4 & 14,6 & 53,2 \\
\hline & Szlovákia & 4,9 & 0,1 & 2,3 \\
\hline & Szlovénia & 14,8 & 1,2 & 10,0 \\
\hline \multirow{4}{*}{ II. } & Belgium & 70,9 & 21,0 & 28,5 \\
\hline & Írország & 59,3 & 5,2 & 10,5 \\
\hline & Luxemburg & 109,7 & 0,2 & 0,2 \\
\hline & Málta & 39,0 & 0,6 & 1,7 \\
\hline \multirow{4}{*}{ III. } & Finnország & 57,2 & 56,6 & 86,1 \\
\hline & Franciaország & 77,3 & 40,1 & 53,2 \\
\hline & Hollandia & 86,7 & 52,8 & 63,4 \\
\hline & Németország & 47,4 & 33,3 & 69,1 \\
\hline \multirow{2}{*}{ IV. } & Olaszország & 28,0 & 65,8 & 138,0 \\
\hline & Spanyolország & 75,9 & 86,3 & 99,9 \\
\hline
\end{tabular}

\footnotetext{
${ }^{20} \mathrm{http}: / /$ databank.worldbank.org/data/source/global-financial-development (Letöltés ideje: 2018. június 4.)
} 